Article

\title{
Forest Soil Cation Dynamics and Increases in Carbon on the Allegheny Plateau, PA, USA Following a Period of Strongly Declining Acid Deposition
}

\author{
Scott W. Bailey ${ }^{1, *} \mathbb{C}$, Robert P. Long ${ }^{2}$ and Stephen B. Horsley ${ }^{2}$ \\ 1 USDA Forest Service, Northern Research Station, North Woodstock, NH 03262, USA \\ 2 USDA Forest Service, Northern Research Station, Irvine, PA 16329, USA; robert.long1@usda.gov (R.P.L.); \\ sbhorsley@verizon.net (S.B.H.) \\ * Correspondence: scott.bailey@usda.gov; Tel.: +1-603-484-5218
}

Citation: Bailey, S.W.; Long, R.P.; Horsley, S.B. Forest Soil Cation Dynamics and Increases in Carbon on the Allegheny Plateau, PA, USA Following a Period of Strongly Declining Acid Deposition. Soil Syst. 2021, 5, 16. https://doi.org/10.3390/ soilsystems 5010016

Academic Editor: Heike Knicker

Received: 3 February 2021

Accepted: 11 March 2021

Published: 12 March 2021

Publisher's Note: MDPI stays neutral with regard to jurisdictional claims in published maps and institutional affiliations.

Copyright: (c) 2021 by the authors. Licensee MDPI, Basel, Switzerland. This article is an open access article distributed under the terms and conditions of the Creative Commons Attribution (CC BY) license (https:// creativecommons.org/licenses/by/ $4.0 /)$.

\begin{abstract}
Reductions in exchangeable calcium and magnesium and increase in exchangeable aluminum concentrations have been shown in soils impacted by acid deposition, including at four sites on the Allegheny Plateau, PA, USA, sampled in 1967 and 1997 during a period of peak deposition. We repeated sampling at these sites in 2017 to evaluate changes in soils during the more recent period when there has been a strong decline in acid deposition. The uppermost horizons, including the $\mathrm{Oa}$ and A horizons where humified organic matter transitions to mineral soil, were thicker, had higher concentrations of organic carbon and exchangeable calcium and magnesium, and lower concentrations of exchangeable aluminum in 2017 compared to 1997, approximating values measured in 1967. Below the Oa/A horizons, 2017 soil chemistry was more similar to the 1997 results, with some reduction of $\mathrm{Ca}$ in the recent measurements. These results suggest recovery of base cationaluminum balance in surface horizons and may indicate a reduction of aluminum mobilization and increased efficiency of vegetation recycling of nutrients with decreased acid anion concentrations. These changes are consistent with a partial recovery from acid deposition. However, the increase in humified soil organic matter may also be affected by coincident increases in temperature and soil moisture.
\end{abstract}

Keywords: forest soil; soil acidification; acid deposition; climate change; soil monitoring; soil organic matter; soil carbon; calcium; aluminum; magnesium

\section{Introduction}

In the absence of active management or direct disturbance, soils develop over millennial time scales and may be quite stable at the decadal and shorter time scales of the human perspective. Indeed, most documentation of temporal soil change involves changes in management or vegetation cover [1]. Relatively long-term ecological studies of unmanipulated reference sites, at decadal or less time scales, typically consider soils to be temporally invariant [1]. As an example, the forested unglaciated Allegheny Plateau in Pennsylvania (PA) hosts some of the most northern Ultisols found in eastern North America [2]. Soil forming processes such as primary mineral weathering, secondary clay formation and translocation, and fragipan development over many tens to hundreds of thousands of years have resulted in Ultisols in this district $[3,4]$. On the other hand, soil chemical properties controlled by ion exchange sites on the surface of organic matter and clay particles may change more rapidly. These reflect changes in solute fluxes and organic matter turnover on seasonal to annual time scales, following changes in vegetation cover, land management, or disturbance. Growing appreciation for response to disturbance or changes in the environment has led to increased attention to shorter time scale soil dynamics [5] and fostered the establishment of soil monitoring programs [6,7]. 
Atmospheric acid deposition is a global phenomenon that developed during the 20th century with increased industrialization and development of tall stacks to dissipate emissions $[8,9]$. This sudden alteration in the chemical composition of rain, snow and particulate deposition led in some cases to soil acidification, a loss of exchangeable base cations, such as calcium and magnesium, and a concomitant increase in ionic forms of aluminum, as shown by retrospective soil sampling studies [10-13] as well as catchment scale mass balance studies [14,15], and acidification experiments [16]. In the United States, the largest loads of acid deposition have occurred in the northeastern part of the country [8,9], particularly in the area of western PA, falling on soils such as the above mentioned Ultisols that formed in response to the limited mineral weathering potential of clastic parent materials [2]. Indeed, in a previous study, we documented reductions in $\mathrm{pH}$, an order of magnitude reduction in exchangeable calcium and magnesium, and increases in exchangeable aluminum in a retrospective study comparing soil chemistry in 1967 and 1997 at four mixed deciduous forest locations with Ultisols on the unglaciated Appalachian Plateau in northwestern PA. This sampling period coincided with the period of peak acid deposition, particularly the deposition of sulfate, which had its highest deposition in the United States in the region of the Allegheny Plateau [9].

Acid deposition levels in northeastern North America peaked in the 1970's and continue to decline with over an $80 \%$ reduction in both wet and dry sulfate deposition between 1980 and 2017 [9]. During this period of an increase followed by a sharp decrease in acid deposition, there has been no management activity or disturbance events at the forested sites where soils were investigated in 1967 and 1997, presenting an opportunity to return and sample soils once more to evaluate possible soil responses to strong declines in sulfate deposition. In other parts of northeastern North America impacted by acid deposition, small but significant changes in forest soil chemistry suggest the start of a recovery from soil acidification impacts $[17,18]$. However, any progress toward recovery has yet to be investigated in more vulnerable soils such as these unglaciated Ultisols in the area of peak acid deposition on the Allegheny Plateau.

In 2017, we returned to these sites and resampled them following the same design and methods we used in 1997. Together with the earlier sampling in 1967 [19] this creates a fifty-year record of forest soils that surrounds the period of peak acid deposition. Due to the lack of weatherable primary minerals in these unglaciated soils, we hypothesize that recovery, if detectable, might be less than that detected in younger glaciated soils. The objective of the present study is to use the same methods and sites sampled in 1997 and 2017 to evaluate signs of recovery of soil $\mathrm{pH}$, and exchangeable cations following reduction in acid deposition. In addition, we evaluate changes in soil organic carbon at the same sites. Although soil carbon dynamics were not studied previously [11] this is particularly important due to the role of carbon in cation exchange in these soils. We measured carbon content of samples from 1997 we previously archived and compared the results to new samples collected in 2017.

\section{Materials and Methods}

\subsection{Site Description and Field Methods}

During a soil survey of Warren County, PA, USA in 1967, twelve sampling sites were established, representing both forest and agricultural areas and spanning the range of soils encountered [19]. The locations of these sites were well documented, and subsamples were archived at Pennsylvania State University. In 1997, we determined that two of the six forested sites previously studied were intact, with no significant disturbance or management. Two others had local management activity but similar soils under the same forest stand could be sampled by moving approximately $30 \mathrm{~m}$ from the original pit location. Along with Robert Cunningham, who was one of the samplers and authors of the original study, we resampled these sites and reported on changes in soil chemistry over the intervening thirty year period [11]. In 2017, all three co-authors of the thirtyyear investigation returned to the four sites and resampled the soils following a similar 
design to that used in 1997, thus extending the record of soil change to fifty years. Soil profile descriptions and all analytical data from the 1967 sampling are included in Ciolkosz et al. [19]. All soil profile descriptions and analytical data collected by us in 1997 and 2017 are in the USDA Forest Service Research Data Archive [20].

All four sites $\left(41.6-41.8^{\circ} \mathrm{N}, 79.0-79.2^{\circ} \mathrm{W}\right)$ are on the Allegheny National Forest and support fully stocked [21], mature second growth forest that originated following harvests between 1890 and 1930 [22]. Vegetation consists of diverse species, predominantly mixed oak at Dewdrop (DD) and Hearts Content (HC), and northern hardwoods at Fools Creek (FC) and North Branch (NB). An index map and full details of vegetation history and stand composition and structure measurements are given in the supplemental information (see supplemental Figure S1 and Tables S1-S5).

The sites are on the unglaciated portion of the Allegheny Plateau and all occupy plateau top physiographic positions near the local height of land. The reference names of the four sites, their elevations, map unit designations and soil taxonomy in the 1967 survey were: (1) Dewdrop (DD; elev. 628 m), S67 PA 62-6, Cookport taxadjunct very stony silt loam, Aquic Fragiudalf, fine-loamy, mixed, mesic; (2) Fools Creek (FC; elev. 543 m, S67 PA 62-4, Cookport very stony loam, Aquic Fragiudult, fine-loamy, mixed, mesic; (3) Hearts Content (HC; elev. 573 m, S67 PA 62-2, Hazleton taxadjunct channery sandy loam, Typic Dystrochrept, loamy-skeletal, mixed, mesic; (4) North Branch (NB; elev. 622 m, S67 PA 62-5, Dekalb channery fine sandy loam, Typic Dystrochrept, loamy-skeletal, mixed, mesic [19]. Soils were very deep and were described and sampled to depths ranging from 130 to 171 $\mathrm{cm}$. Bedrock was encountered at the base of the sampling pits only at NB.

In 1997, four new pits were opened in cardinal directions $10 \mathrm{~m}$ from the $1967 \mathrm{pit}$ at DD and HC. At FC and NB, the 1997 pits were about $30 \mathrm{~m}$ from the 1967 pit. In 2017, four additional pits at each site were opened and sampled, located in between the pits established in 1997. Soil profiles were described and sampled by genetic horizons according to the same sampling protocols used in the 1967 survey [19]. Previous analysis of 1967-1997 soil change was published to evaluate response to elevated acidic deposition [11]. In the present study, we focus on soil change between the 1997 and 2017 samplings, representing a period of sharply declining acid deposition. The pit samples were used to evaluate change in soil chemistry at the whole pedon level. Additional soil samples from forest floor horizons were taken in 1997, 1998, and 1999 and 2017 via the pin block method [11,23]. Thus, we have two methods-grab samples from pit faces and forest floor pin blocks to evaluate dynamics in the primary rooting horizons of the Oa and A horizons.

In each of the four quadrants between two adjacent pits we established three linear transects for pin blocks, each having four potential sample points at 1-m intervals [11]. One transect in each quadrant was sampled in 1997, 1998, and 1999, respectively. In each of the three sample years, 10 of the possible 16 sample points were randomly chosen and a 10 by $10 \mathrm{~cm}$ pin-block sample was taken from each point. In 2017, four additional pin block samples were collected from each transect, yielding a total of 16 samples at each site. As we previously reported no statistically significant differences in forest floor thickness or chemistry between the three sampling years in the 1990's [11], here we only compare the 1997 pin block data with 2017 pin blocks to evaluate possible changes in forest floor thickness, mass per unit area, and chemistry across the twenty year period.

The presence and thickness of $\mathrm{Oa}$ and A horizons was variable over short distances; sometimes it was possible to identify one, the other, or both at individual pits or pin blocks. When both were present, the A was always immediately beneath the Oa. Differentiation of an Oa from an A horizon is defined by an organic carbon concentration of $20 \%$ by weight [24]. However, many of these horizons had a carbon concentration near that threshold and it is impossible to exactly differentiate Oa vs. A horizons in the field. Thus, we sampled to the base of the A horizons and separated the base of the pin blocks at the first appearance of an E or B horizon. A strong color and bulk density contrast made this boundary easy to separate with a sharp knife. When laboratory data were received, we corrected designations of Oa versus A horizons to fit the organic carbon content definition. 
For each pin block, the thickness of each horizon was measured to the nearest $0.5 \mathrm{~cm}$. For some Oi (i.e., relatively undecomposed forest litter; $\geq 40 \%$ rubbed fiber content [24]) and Oe (i.e., partially decomposed litter; the fermentation layer; rubbed fiber content $<40 \%$ and $\geq 17 \%$ [24]) horizons, only a trace thickness was observed. These were assigned a thickness of $0.25 \mathrm{~cm}$. As the $\mathrm{Oi}$ and Oe were very thin, the thickness and unit area mass of these horizons was combined for statistical purposes. Thus, we compared the thickness and unit area mass of an Oie horizon between 1997 ( $n=10$ per site) and 2017 ( $n=16$ per site). The $\mathrm{Oa}$ and A horizons, consisting of humified organic matter mixed with mineral soil were also combined for statistical purposes because of their variable presence and difficulty of differentiating the break between these two horizons in the field. Thickness of the $\mathrm{Oa} / \mathrm{A}$ horizons were measured and these samples were then dried and subject to the same chemical analyses as the horizon samples for the pits. In 1997, only A horizons were identified in pin blocks in the field. However, laboratory analyses revealed that 13 of the 40 pin blocks had Oa horizons. In 2017, budget limitations led us to combine the pin blocks in each quadrant at each site before chemical analysis. Thus, only four Oa and A samples from pin blocks per site were available for chemistry comparison. In 2017, field examination suggested that there was both an $\mathrm{Oa}$ and A present at 60 of the 64 pin blocks with the remaining four only having an A horizon. After compositing and based on organic carbon concentrations, we had 15 pin block composites with both an $\mathrm{Oa}$ and $\mathrm{A}$ and 1 pin block composite with an A. Combination of $\mathrm{Oa}$ and $\mathrm{A}$ analyses was made by weighting the chemical concentration of each by the proportion of the unit area mass contained in each horizon.

\subsection{Sample Processing and Analytical Methods}

All samples considered in this study, including the 1967 samples, were collected during the month of July. Soil samples were air-dried and screened to remove particles greater than $2 \mathrm{~mm}$. Samples were then homogenized by mixing via in a riffle splitter. Subsamples for analysis were obtained by riffle sampling and repeated mixing via a plastic scoop to avoid variability induced by separation of soil particles along size or density gradients. Samples were analyzed for $\mathrm{pH}$ in $0.01 \mathrm{~mol} \mathrm{~L}^{-1} \mathrm{CaCl}_{2}$ [25]. Exchangeable cations ( $\mathrm{Ca}, \mathrm{Mg}, \mathrm{Al}$ ) were determined in $1 \mathrm{~mol} \mathrm{~L}^{-1} \mathrm{NH}_{4} \mathrm{Cl}$ extracts obtained by mechanical vacuum extraction [26]. Concentrations of all cations in soil extracts were measured with a Varian Vista axial inductively coupled plasma spectrophotometer. Exchangeable cations were expressed on an oven-dry mass basis (cmolc $\left.\mathrm{kg}^{-1}\right)$. Detection limits for exchangeable cation analyses were equivalent to 0.006 and 0.004 cmolc kg ${ }^{-1}$ for $\mathrm{Ca}$ and $\mathrm{Mg}$, respectively. The few analyses that were below the detection limit were assigned a value of one-half of the detection limit. All measured Al concentrations were well above detection limit. A subset of samples were analyzed in triplicate and varied within $15 \%$ of mean values. We routinely measure the chemistry of reference $\mathrm{Oa}$ and Bs horizon samples which yielded results consistent with our prior work on these samples and generally in agreement with other laboratories [27].

The 1997 and 2017 samples, and reanalysis of archived samples were all conducted in the USDA Forest Service laboratory in Durham, NH using the same protocols and with overlapping personnel. Archived subsamples of soils collected in 1967 and 1997 were analyzed for $\mathrm{pH}$ and exchangeable cations by the same methods used for the new samples. These analyses were compared with the original results [11,19] to determine comparability of methods. Ciolkosz et al. [19] used similar methods to analyze the 1967 samples for $\mathrm{pH}$ and exchangeable $\mathrm{Al}$, while exchangeable bases were determined in a $\mathrm{pH} 7$ ammonium acetate extract. We found no difference between the two extraction methods for exchangeable $\mathrm{Ca}$ or $\mathrm{Mg}$, similar to the results of Ross et al. [27].

Organic carbon content was originally measured on the 1967 samples [19] but was not measured by us on in our original study of the 1997 samples. In 2017, we analyzed the new samples and archived 1967 and 1997 samples for carbon content by combustion on a Shimadzu TOCV with TNM-1 nitrogen detector. Our new analyses of the 1967 archived 
samples showed similar organic carbon concentrations to those originally reported by Ciolkosz et al. [19].

\subsection{Statistical Methods}

To test the statistical significance of differences in chemistry of the soil profiles sampled from the pits, we chose to compare four discrete horizons or depths. The Oa and A horizon data were combined and considered as one horizon for statistical purposes, due to their variable presence at individual sampling sites and the difficulty in distinguishing and cleanly separating these horizons in the field. We then compared the chemistry of the first horizon beneath the $\mathrm{Oa}$ and $\mathrm{A}$ horizons, generally an $\mathrm{E}$ or B horizon; these ranged as shallow as $3 \mathrm{~cm}$ and as deep as $26 \mathrm{~cm}$ below the soil surface although they were generally toward the lower end of this whole range. Finally, we evaluated changes in chemistry of the horizons that straddled depths of $50 \mathrm{~cm}$ and $100 \mathrm{~cm}$ below the soil surface. The former was some sort of $B$ horizon while the later included $B$ and $C$ horizons.

To evaluate changes in forest floor $\mathrm{O}$ and $\mathrm{A}$ horizons sampled by pinblocks, we combined the Oi and Oe horizons, composed of partially decomposed organic matter, and we combined the $\mathrm{Oa}$ and A horizons, composed of humified organic matter mixed with variable amounts of mineral matter. For thickness and unit area mass, we simply added the Oa and A horizons together. For chemical concentrations, we calculated a weighted average based on the proportion of the total unit area mass contained by each horizon. We evaluated temporal changes in combined $\mathrm{Oi} / \mathrm{Oe}$ and $\mathrm{Oa} / \mathrm{A}$ thickness and mass per unit area, and changes in the chemistry of the $\mathrm{Oa} / \mathrm{A}$ horizons.

The statistical analyses of differences in soil physical and chemical measures were tested using a generalized linear mixed model with PROC GLIMMIX using a restricted or pseudo maximum likelihood estimation technique in SAS 9.4 [28]. We used a nested completely randomized design with fixed effects of site, year, and the site by year interaction. Pits within sites were a random effect in the models, and the Kenward-Rogers method was used to adjust the denominator degrees of freedom [29]. Normality of the residuals was assessed using the Shapiro-Wilk test and alternative distributions including the lognormal (with the identity link function) and gamma (with the log link function) were used to obtain the model with the best fit when warranted. All model terms were assessed at the $\alpha=0.05$ significance level. Homogeneity of variance was assessed for the fixed effects via boxplots and Levene's test and adjustment with the group = option was made when warranted. Statistical analyses were conducted on a hydrogen ion concentration basis, with the results converted back to $\mathrm{pH}$ for reporting.

\section{Results}

Soil profile chemistry in 2017 was fairly similar to the results from 1997, indicating a strong reduction in exchangeable $\mathrm{Ca}$ and $\mathrm{Mg}$, a reduction in $\mathrm{pH}$ and an increase in exchangeable Al compared to 1967 measurements [11]. The exception to this pattern was observed in the uppermost portions of the profile, primarily at a depth less than $10 \mathrm{~cm}$, where the 2017 exchangeable $\mathrm{Ca}$ and $\mathrm{Mg}$ values were similar to the 1967 measurements while exchangeable Al concentrations in 2017 were intermediate between 1967 and 1997. This apparent recovery in the upper part of the profile was associated with a change in soil morphology, with the combined Oa/A thickness having a mean of $3.2 \mathrm{~cm}$ in 1997 and $6.1 \mathrm{~cm}$ in 2017. These results are discussed in detail in the following section, illustrated by soil profile chemistry graphs with average values reported for each site and year. For a more complete picture, all profiles (one per site in 1967 and four each per site in each of 1997 and 2017) are plotted separately in supplemental Figure S2, best viewed zoomed-in on-screen, which follows the format of the earlier published comparison of the 1967 and 1997 soil profiles [11] and includes all samples collected from pits in all three years. 


\subsection{Whole Profile Chemistry}

Soil $\mathrm{pH}$ ranged from 3.0 to 5.2 with the largest range and change over time shown at one site, DD (Figure 1). Variation in $\mathrm{pH}$ with depth was inconsistent. In most cases $\mathrm{pH}$ varied the greatest in surficial horizons, with less variation below depths of about $20 \mathrm{~cm}$. Changes in $\mathrm{pH}$ over time were also variable. At DD there was a strong decrease in $\mathrm{pH}$, of almost a whole $\mathrm{pH}$ unit over the entire profile from 1967 to 1997 and a further decrease of about $0.2 \mathrm{pH}$ units from 1997 to 2017. HC showed little difference in $\mathrm{pH}$ between 1967 and 1997 but a similar decrease in $\mathrm{pH}$ as that seen at DD between 1997 and 2017. The clearest decline in $\mathrm{pH}$ from 1967 to 1997, during peak acid deposition, was at FC and NB. At FC at all depths, and at NB only in the shallowest horizons, there was some recovery with higher pH in 2017 compared to 1997.

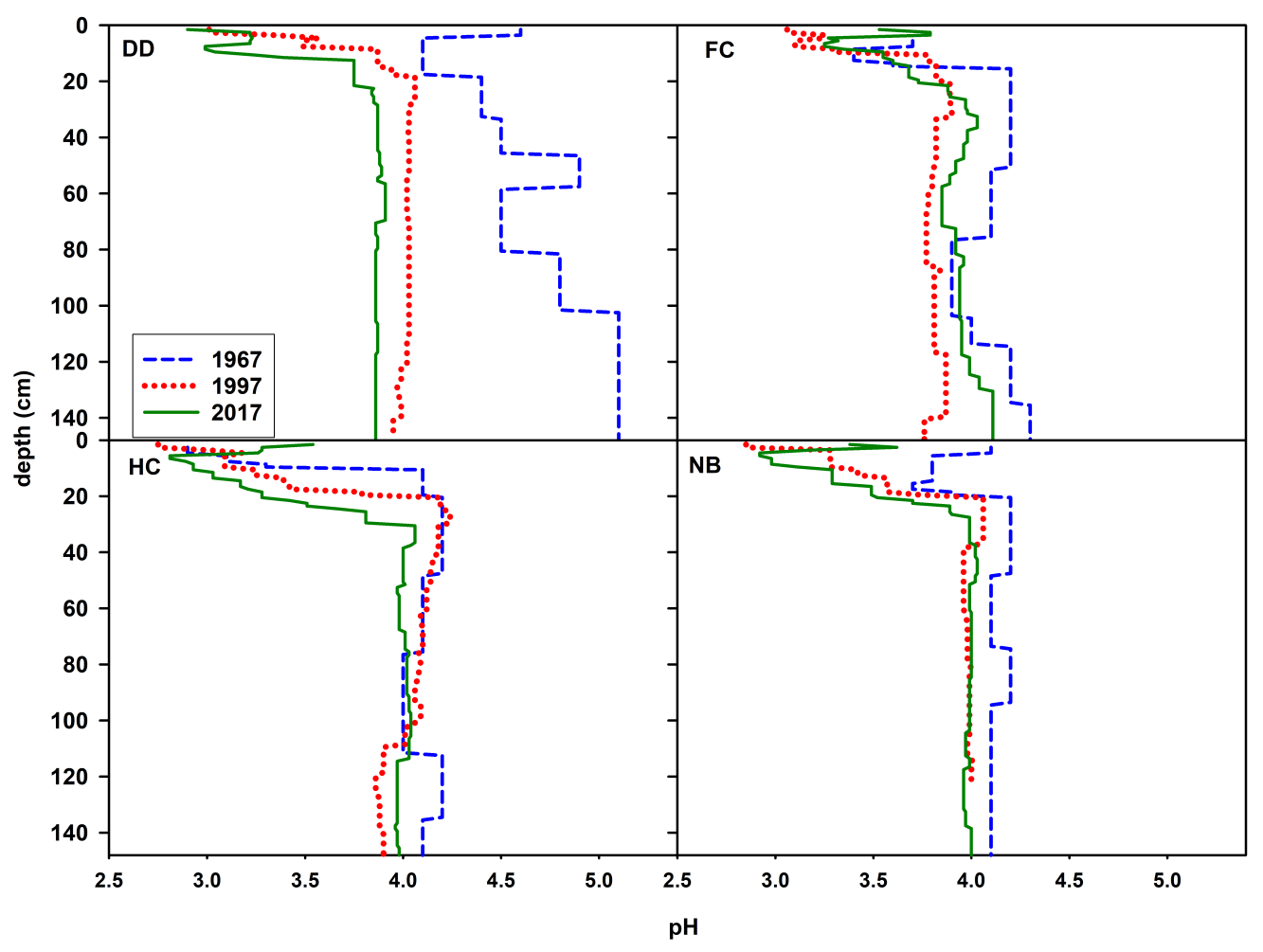

Figure 1. Soil $\mathrm{pH}$ profiles with depth. At each site, there was one profile in 1967. In 1997 and 2017, four soil profiles were sampled at each site. The profile shown for these years was calculated as the average in one cm increments. The 1967 profile is shown in a dashed blue line, 1997 as a dotted red line, and 2017 as a solid green line. The same format is followed for the other chemistry profile figures (Figures 2-5). The supplemental Figure S2 shows each chemical profile individually, i.e., four profiles per site in each of 1997 and 2017.

Over all sites, $\mathrm{pH}$ increased slightly in the Oa/A horizon and decreased slightly in the upper B horizon from 1997 to 2017 . However, these differences were not statistically significant (Table 1). In the mineral soil at depths of 50 and $100 \mathrm{~cm}$, mean $\mathrm{pH}$ each year ranged from 3.96 to 3.98 , the same as the precision of the measurement and without statistical significance (Table 1).

As reported earlier [11], the greatest difference in chemistry between 1967 and 1997 was a reduction in exchangeable $\mathrm{Ca}$ and $\mathrm{Mg}$ concentrations, by about an order of magnitude at all sites and depths. In 2017, there was a recovery of $\mathrm{Ca}$ and $\mathrm{Mg}$ concentrations at depths less than about $10 \mathrm{~cm}$ at all four sites, whereas the remainder of the 2017 profiles of these cations were more similar to the 1997 results (Figures 2 and 3). At DD and FC, the average profiles for $\mathrm{Ca}$ and $\mathrm{Mg}$ are very similar at depth, whereas at $\mathrm{HC}$ and $\mathrm{NB}$, there was a slight reduction in $\mathrm{Ca}$ and $\mathrm{Mg}$ concentrations from 1997 to 2017 deeper in the mineral soil. 
Table 1. Least squares means (standard error) for exchangeable element concentrations of $\mathrm{Ca}, \mathrm{Mg}, \mathrm{Al}$, and $\mathrm{pH}$, and $\mathrm{C}$ for the Oa/A, upper mineral horizon (E/B), B at $50 \mathrm{~cm}$ depth and B/C at $100 \mathrm{~cm}$ depth in 1997 and 2017. Sample number is 16 for each comparison $(4$ sites $\times 4$ pits per site).

\begin{tabular}{|c|c|c|c|c|c|c|c|c|c|c|c|c|}
\hline \multirow[b]{2}{*}{ Property } & \multicolumn{3}{|c|}{ Oa/A Horizon } & \multicolumn{3}{|c|}{ Uppermost E/B Horizon } & \multicolumn{3}{|c|}{$50 \mathrm{~cm}$ Depth } & \multicolumn{3}{|c|}{$100 \mathrm{~cm}$ Depth } \\
\hline & 1997 & 2017 & $\mathbf{P}$ & 1997 & 2017 & $\mathbf{P}$ & 1997 & 2017 & $\mathbf{P}$ & 1997 & 2017 & $\mathbf{P}$ \\
\hline $\begin{array}{c}\mathrm{Ca}, \\
\mathrm{cmol}_{\mathrm{c}} \mathrm{kg}^{-1}\end{array}$ & $\begin{array}{c}0.836 \\
(0.120)\end{array}$ & $\begin{array}{c}3.045 \\
(0.437)\end{array}$ & $<0.001$ & $\begin{array}{c}0.075 \\
(0.009)\end{array}$ & $\begin{array}{c}0.048 \\
(0.006)\end{array}$ & $0.018^{1}$ & $\begin{array}{c}0.042 \\
(0.008)\end{array}$ & $\begin{array}{c}0.016 \\
(0.003)\end{array}$ & 0.014 & $\begin{array}{l}0.049 \\
(0.16)\end{array}$ & $\begin{array}{c}0.025 \\
(0.008)\end{array}$ & 0.048 \\
\hline $\begin{array}{c}\mathrm{Mg}^{\prime} \\
\mathrm{cmol}_{\mathrm{c}} \mathrm{kg}^{-1}\end{array}$ & $\begin{array}{c}0.382 \\
(0.066)\end{array}$ & $\begin{array}{c}1.081 \\
(0.066)\end{array}$ & $<0.001$ & $\begin{array}{c}0.049 \\
(0.005)\end{array}$ & $\begin{array}{c}0.048 \\
(0.005)\end{array}$ & 0.933 & $\begin{array}{c}0.013 \\
(0.003)\end{array}$ & $\begin{array}{c}0.018 \\
(0.004)\end{array}$ & 0.256 & $\begin{array}{c}0.017 \\
(0.004)\end{array}$ & $\begin{array}{c}0.022 \\
(0.006)\end{array}$ & 0.251 \\
\hline $\begin{array}{c}\mathrm{Al}, \\
\mathrm{cmol}_{\mathrm{c}} \mathrm{kg}^{-1}\end{array}$ & $\begin{array}{c}5.898 \\
(0.370)\end{array}$ & $\begin{array}{c}4.458 \\
(0.370)\end{array}$ & 0.031 & $\begin{array}{c}7.446 \\
(0.607)\end{array}$ & $\begin{array}{c}3.478 \\
(0.284)\end{array}$ & $<0.001^{1}$ & $\begin{array}{c}3.824 \\
(0.237)\end{array}$ & $\begin{array}{c}3.885 \\
(0.237)\end{array}$ & 0.872 & $\begin{array}{c}2.866 \\
(0.286)\end{array}$ & $\begin{array}{c}2.429 \\
(0.286)\end{array}$ & 0.403 \\
\hline $\mathrm{pH}$ & $\begin{array}{c}2.90 \\
(0.08)\end{array}$ & $\begin{array}{c}3.00 \\
(0.08)\end{array}$ & 0.302 & $\begin{array}{c}3.24 \\
(0.08)\end{array}$ & $\begin{array}{c}3.16 \\
(0.08)\end{array}$ & 0.670 & $\begin{array}{c}3.98 \\
(0.02)\end{array}$ & $\begin{array}{c}3.96 \\
(0.02)\end{array}$ & 0.472 & $\begin{array}{c}3.98 \\
(0.03)\end{array}$ & $\begin{array}{c}3.96 \\
(0.03)\end{array}$ & 0.664 \\
\hline $\begin{array}{l}\text { C, percent } \\
\text { dry mass }\end{array}$ & $\begin{array}{l}12.95 \\
(1.23)\end{array}$ & $\begin{array}{l}27.19 \\
(1.23)\end{array}$ & $<0.001$ & $\begin{array}{c}1.58 \\
(0.21)\end{array}$ & $\begin{array}{c}2.22 \\
(0.21)\end{array}$ & 0.109 & $\begin{array}{c}0.31 \\
(0.04)\end{array}$ & $\begin{array}{c}0.52 \\
(0.07)\end{array}$ & 0.013 & NA & & \\
\hline
\end{tabular}

${ }^{1}$ A significant site $\times$ year interaction effect indicates that there was not a significant effect by year alone. This occurred when the change was not consistently seen across all four sites.

Over all sites, mean exchangeable $\mathrm{Ca}$ and $\mathrm{Mg}$ in the $\mathrm{Oa} / \mathrm{A}$ horizon was over three times larger in 2017 (Ca 3.04; Mg 1.08) compared to 1997 (Ca 0.84; Mg 0.38), which was significant at $p$-levels $<0.001$ (Table 1). In the mineral soil, Ca decreased in 2017 in the uppermost B horizon (0.075 in 1997 to 0.048 in 2017) although this difference was not significant due to a significant site $\times$ year interaction effect. At $50 \mathrm{~cm}$ depth a decrease in Ca was significant (0.042 in 1997 to 0.016 in 2017; $p=0.014$ ). A reduction in Ca at $100 \mathrm{~cm}$ depth was also significant (0.049 in 1997 to 0.025 in 2017; $p=0.048)$. There were no significant differences in $\mathrm{Mg}$ in any of the three mineral horizons or depths tested (Table 1).

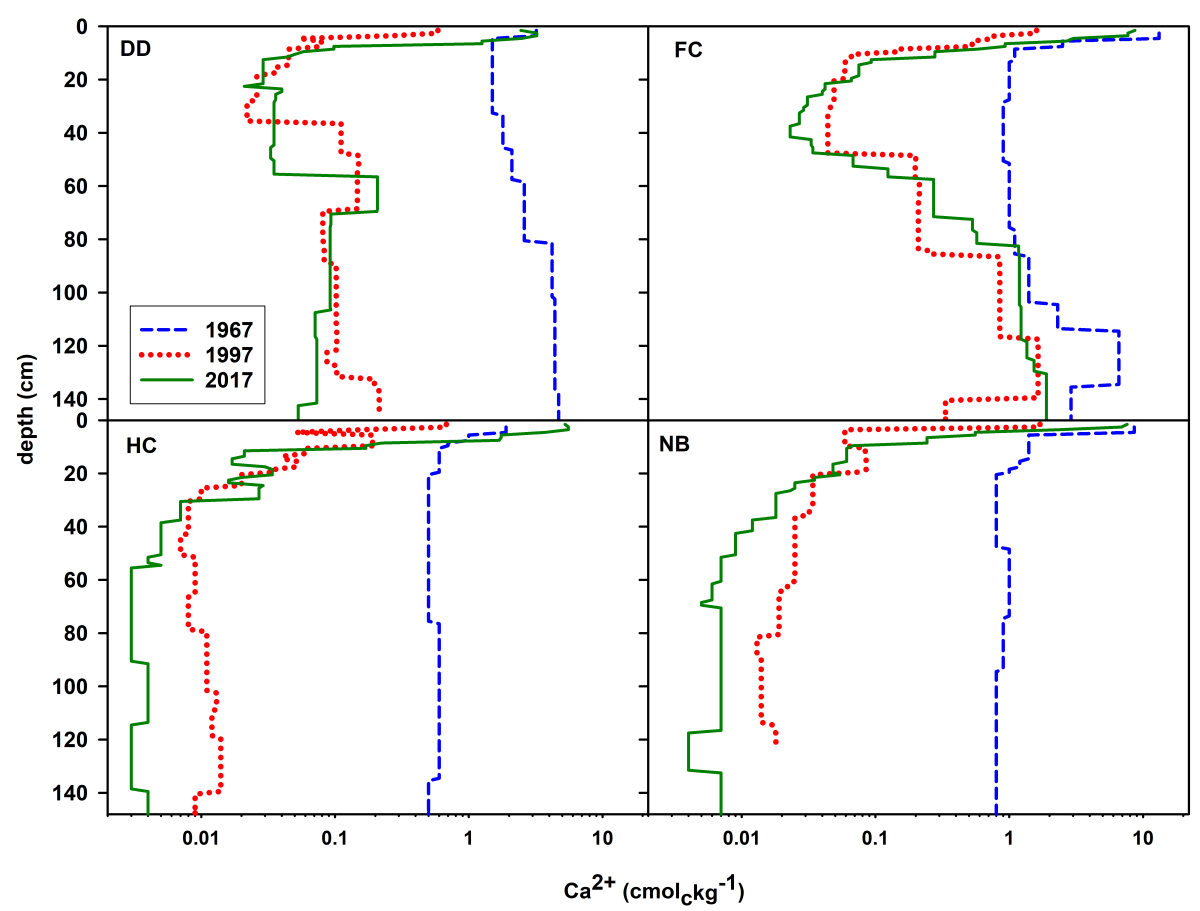

Figure 2. Soil exchangeable Ca profiles. 


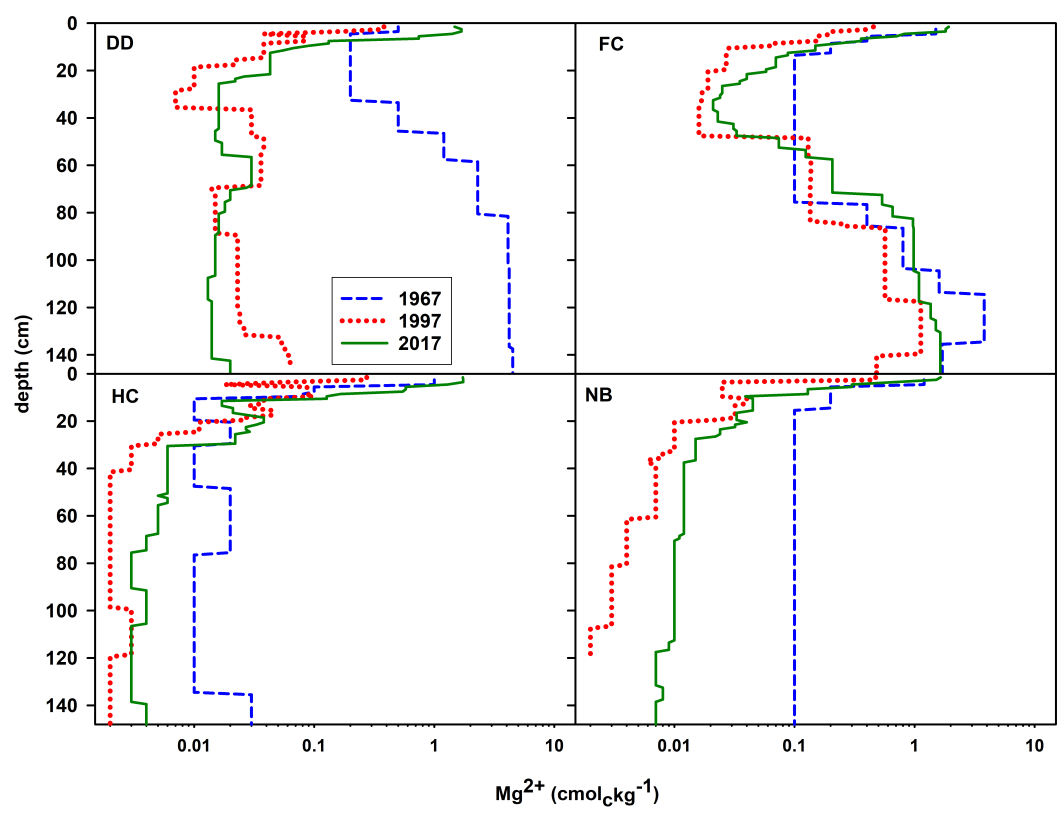

Figure 3. Soil exchangeable Mg profiles.

Exchangeable Al increased between 1967 and 1997, particularly in the upper parts of the profiles [11]. From 1997 to 2017, changes were variable with depth (Figure 4). There was a significant decrease in $\mathrm{Al}$ in the Oa/A horizon (mean 5.90 in 1997 to 4.46 in 2017; $p=0.031$ ), which is about half way back to the mean concentration of 3.3 measured in 1967 [11]. In the upper mineral horizon, a decrease in $\mathrm{Al}$ by about $50 \%$ was noted but was not significant due to a significant site $\mathrm{x}$ year interaction driven by increasing $\mathrm{Al}$ concentration over time at $\mathrm{DD}$ and $\mathrm{FC}$ versus decreases in $\mathrm{Al}$ concentrations at $\mathrm{HC}$ and $\mathrm{NB}$ (Table 1; Figure 4). No significant differences were noted in the Al concentrations between 1997 and 2017 at 50 or $100 \mathrm{~cm}$ depths.

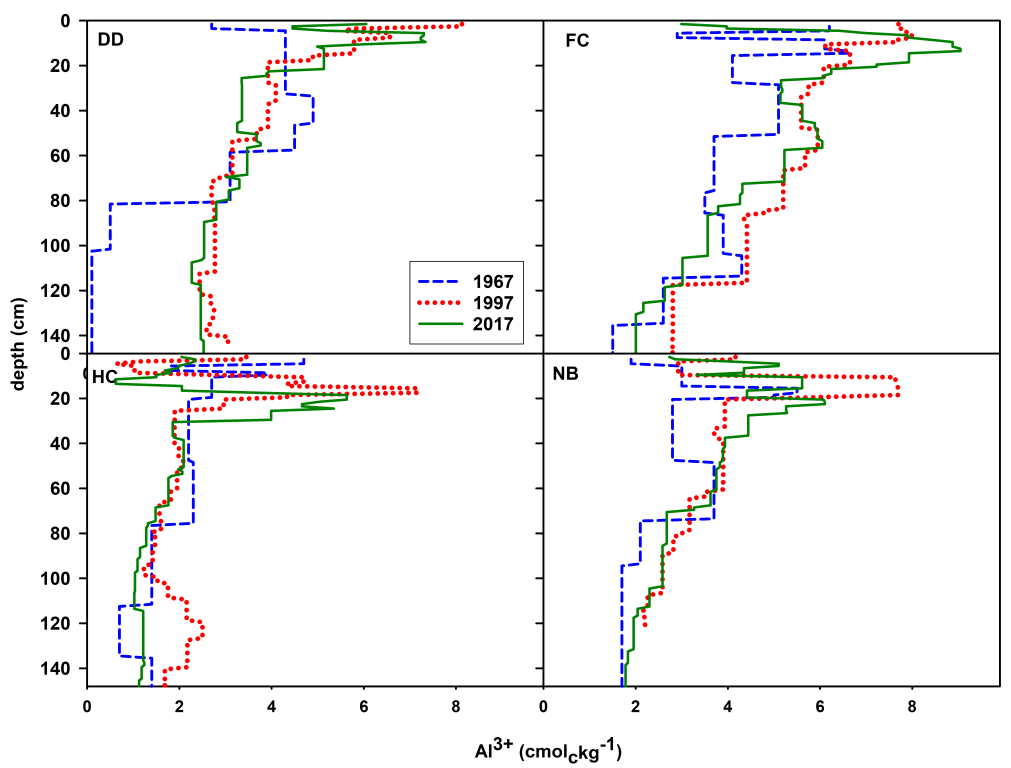

Figure 4. Soil exchangeable Al profiles.

Soil organic carbon concentrations were not considered in our earlier study [11] and were not in the original measurements made on the 1997 samples, although they were measured in the original study of the 1967 samples [19]. Following the 2017 sampling, 
we measured carbon concentrations on samples from all three years to a depth of $80 \mathrm{~cm}$. Our new measurements of carbon in archived 1967 samples agreed well with the original measurements. At DD, the carbon profiles in 1967 and 1997 were very similar while in 2017 concentrations were higher across the profile. At the other three sites, concentrations in the uppermost portion of the profiles decreased from 1967 to 1997, and then increased again with 2017 values similar to 1967 values except in the Oa/A horizons where 2017 samples were higher than observed in previous years. Combined Oa/A samples had a mean organic $\mathrm{C}$ content of $12.9 \%$ in 1997, within the range of an A horizon, whereas they had a mean more than $100 \%$ greater, $27.2 \%$ in 2017 , within the range of an Oa horizon, a difference that was significant with a $p$ value $<0.001$ (Table 1). In 1997 only one horizon was described and sampled in each pit-either an Oa or in most cases an A horizon and it was too thin to subdivide into two horizons. In 2017, all pits had a thicker zone where humic materials and mineral matter mixed, so it was possible to subdivide two horizons in this zone. In most cases, the $\mathrm{C}$ content measurements showed these to be an Oa over an $\mathrm{A}$ horizon although in a few pits the $\mathrm{C}$ concentrations were high enough in the lower horizon to designate an $\mathrm{Oa} 1$ and an $\mathrm{Oa} 2$ horizon. Increases in organic $\mathrm{C}$ content in the upper $\mathrm{B}$ horizon and at $50 \mathrm{~cm}$ depth were smaller, about $57 \%$, and were only significant at the $50 \mathrm{~cm}$ depth $(p=0.033)$.

\subsection{Relationships between Cation Change and Carbon}

As the largest changes between the 1997 and 2017 pit data occurred in the shallowest portion of the profiles, generally in the $\mathrm{Oa} / \mathrm{A}$ horizon, within $10 \mathrm{~cm}$ of the soil surface (Table 1), and this is where the highest carbon concentrations were measured (Figure 5), we took a closer look at this portion of the profiles. Figure 6 shows the relationship between exchangeable Ca concentrations and organic carbon concentration in the uppermost horizons, the $\mathrm{Oa}$ and $\mathrm{A}$ horizons. There is a positive correlation between $\mathrm{Ca}$ and $\mathrm{C}$ concentrations in these horizons $(r=0.75)$. In 2017, samples with higher $C$ concentration were found, above the range observed in 1997 or 1967. About half of these horizons, including some horizons at all four sites, had a C concentration above 25\% whereas only one sample in $1967 \mathrm{had}$ a $\mathrm{C}$ concentration in this range. These higher $\mathrm{C}$ concentration horizons were all toward the upper end of the Ca concentrations measured, although the 2017 samples did not extend the upper range in Ca concentrations from what was seen in the 1967 and 1997 horizons. We found similar relationships between exchangeable $\mathrm{Mg}$ and $\mathrm{C}$ although we show only Ca vs. C graphs.

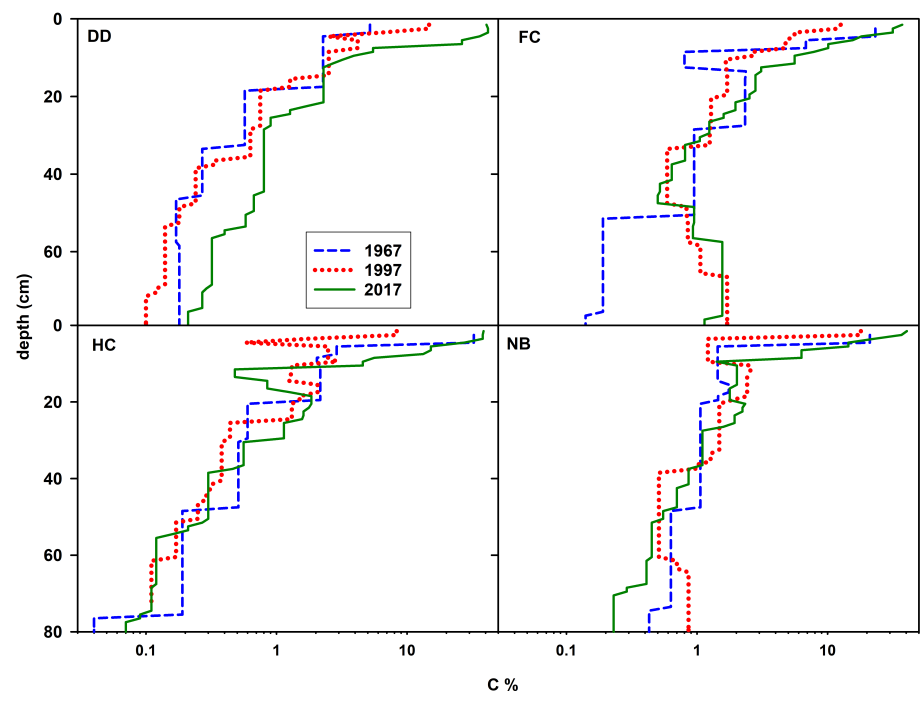

Figure 5. Soil organic carbon concentration profiles to a depth of $80 \mathrm{~cm}$. 


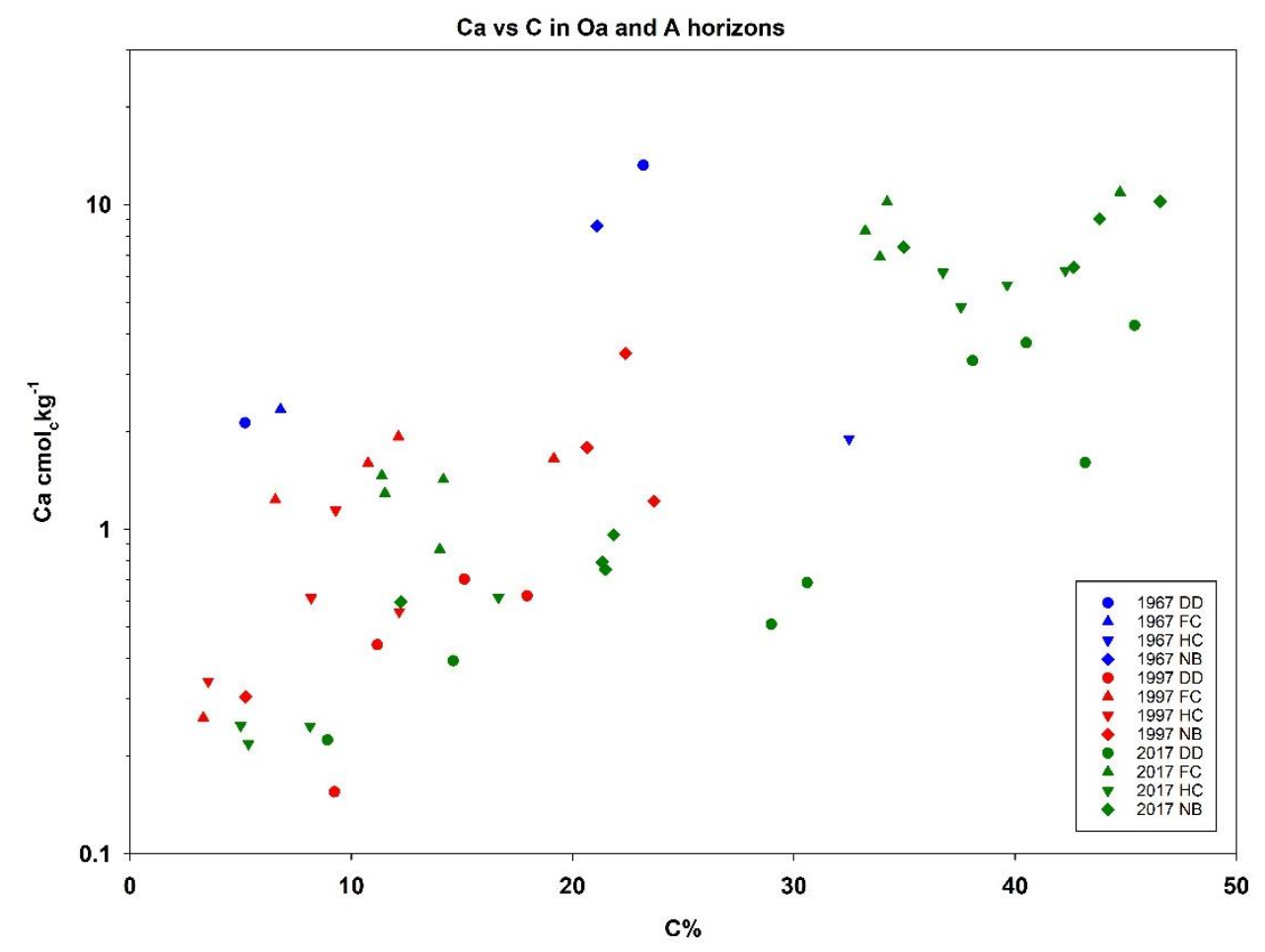

Figure 6. Exchangeable calcium vs. carbon concentration in samples of the Oa and A horizons. Color code follows the same scheme for sampling years as the soil profiles (Figures 1-5). Different symbols denote each of the four sampling sites.

In the uppermost mineral horizon, which was either an $\mathrm{E}$ or a B horizon, there was not a correlation between exchangeable $C a$ and $C(r=0.30$; Figure 7). Like the Oa and A, there was a suggestion of higher $C$ concentrations in this part of the profile in 2017, with five horizon samples from the DD and FC sites with C concentrations above $3.5 \%$. In comparison, none of the upper $\mathrm{E}$ or B horizons sampled in 1967 or 1997 were in this range. Additionally, note that the samples from 1967, while spanning a range of $C$ concentration, all had an exchangeable Ca concentration above $0.4 \mathrm{cmol}_{\mathrm{c}} \mathrm{kg}^{-1}$, a range not observed in any of the 1997 or 2017 samples.

\subsection{Forest Floor Pin Blocks}

Pin blocks were used to quantitatively sample the forest floor $\mathrm{O}$ and $\mathrm{A}$ horizons. With pin blocks, these horizons are completely sampled within a controlled area and separated cleanly with a sharp knife. This increases the probability that shallow surficial horizons are completely sampled and lessens the chance for contamination by adjacent horizons. This also allows more precise measurement of the amount of forest floor present. The thickness of these horizons can be difficult to measure precisely in either pit or pin block samples as they are easily compressed. Pin blocks allow accurate measurement of mass per area, which is a more reproduceable measurement of the amount of the horizon present.

The greatest difference between the 1997 and 2017 forest floor pin blocks was a shift in the type of horizons present, with significant decreases in the thickness and mass of the partially decomposed organic horizons (Oi and Oe) coupled with an increase in the thickness and mass of the Oa and A horizons, composed of well decomposed organic and mineral matter. In 2017, Oie mass per unit area was less than a quarter of what it was in 1997 ( 0.09 and $0.40 \mathrm{~g} \mathrm{~m}^{-2}$, respectively; $p<0.001$; Table 2 ). This reduction in Oie mass was matched numerically by an increase in mass of the Oa and A horizons ( 0.73 in 1997 to $1.04 \mathrm{~g} \mathrm{~m}^{-2}$ in 2017; $p=0.002$ ). Concentrations of exchangeable $\mathrm{Ca}$ and $\mathrm{Mg}$ in the $\mathrm{Oa} / \mathrm{A}$ horizon both increased by about 60\% between 1997 and 2017 while exchangeable $\mathrm{Al}$ in the $\mathrm{Oa} / \mathrm{A}$ horizon decreased by a similar percentage. However, only the Al change was significant $(p<0.001)$ due to significant site $\times$ year interaction effects with $\mathrm{Ca}$ and $\mathrm{Mg}$. The 
organic carbon concentration in the combined Oa/A horizon increased from 14.5\% in 1997, a value within the realm of an A horizon, to $23.4 \%$ in 2017, a value within the range of an Oa horizon. This change was not significant due to the site $\times$ year interaction effect.

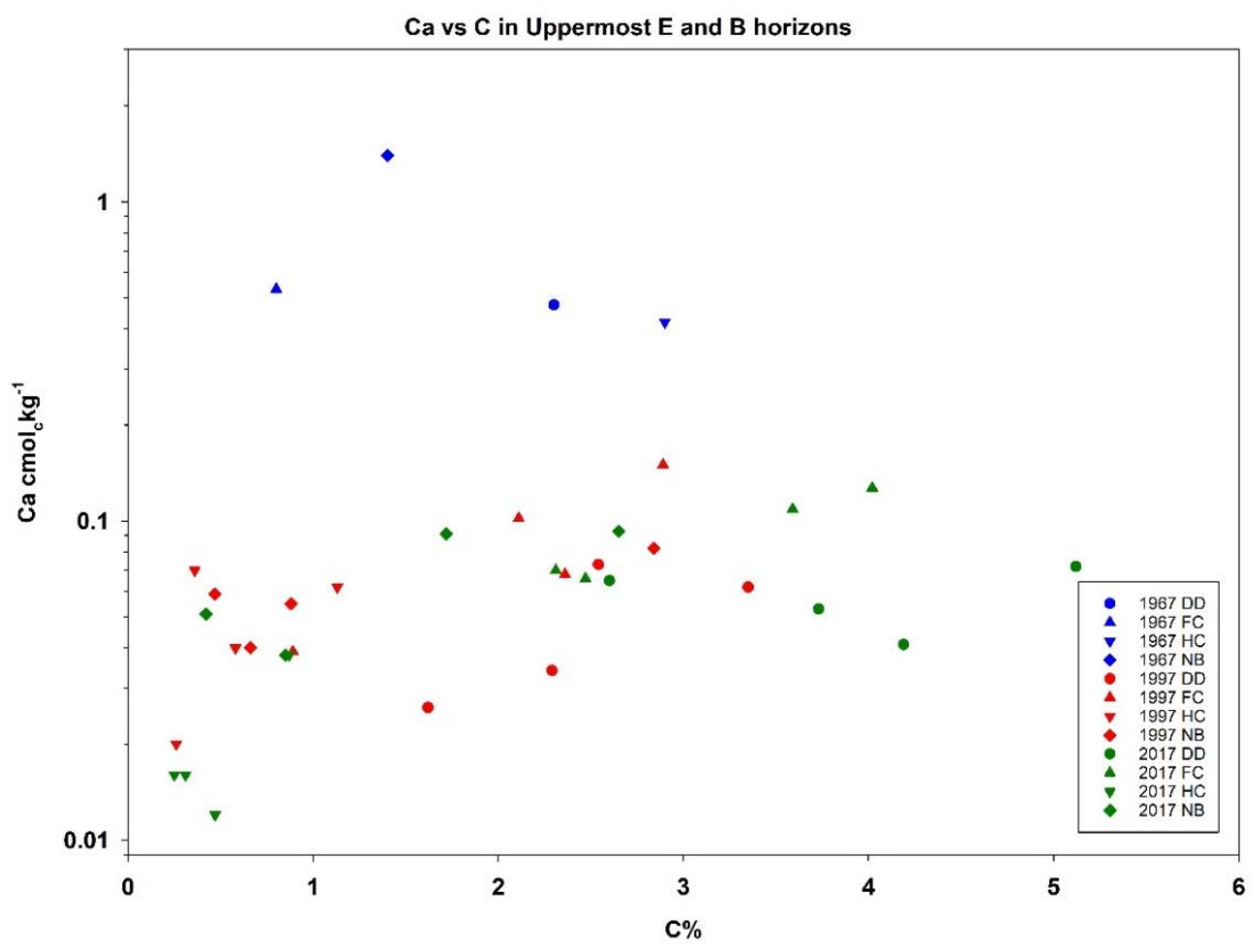

Figure 7. Exchangeable calcium vs. carbon concentration in samples of the E and uppermost B horizons. Color code follows the same scheme for sampling years as the soil profiles (Figures 1-5). Different symbols denote each of the four sampling sites.

Table 2. Least squares means (standard error) for mass per area, thickness, exchangeable concentrations of $\mathrm{Ca}, \mathrm{Mg}, \mathrm{Al}$, and organic carbon content in Oie and Oa/A samples from pin-blocks in 1997 and 2017. Chemical analyses are for the Oa/A sample only. Sample number is 10 pin blocks per site in 1997. In 2017, four pin blocks per quadrant (total 16 pin blocks) were composited to yield 4 measurements per site.

\begin{tabular}{|c|c|c|c|c|c|}
\hline \multirow[b]{2}{*}{ Property } & \multicolumn{2}{|c|}{ Year } & \multicolumn{3}{|c|}{$p$-Value } \\
\hline & 1997 & 2017 & Site & Year & Site $\times$ Year $^{1}$ \\
\hline Oie mass, $\mathrm{g} \mathrm{m}^{-2}$ & $0.40(0.02)$ & $0.09(0.01)$ & 0.014 & $<0.001$ & 0.748 \\
\hline Oie thickness, $\mathrm{cm}$ & $2.56(0.17)$ & $1.14(0.06)$ & $<0.001$ & $<0.001$ & 0.870 \\
\hline $\mathrm{Oa} / \mathrm{A}$ mass, $\mathrm{g} \mathrm{m}^{-2}$ & $0.73(0.05)$ & $1.04(0.12)$ & 0.002 & 0.016 & 0.655 \\
\hline $\mathrm{Oa} / \mathrm{A}$ thickness, $\mathrm{cm}$ & $1.36(0.11)$ & $4.30(0.29)$ & 0.016 & $<0.001$ & 0.362 \\
\hline $\mathrm{Ca}, \mathrm{cmol}_{\mathrm{C}} \mathrm{kg}^{-1}$ & $1.144(0.121)$ & $1.842(0.267)$ & 0.007 & 0.005 & 0.017 \\
\hline $\mathrm{Mg}, \mathrm{cmol}_{\mathrm{C}} \mathrm{kg}^{-1}$ & $0.432(0.032)$ & $0.720(0.064)$ & 0.012 & $<0.001$ & 0.006 \\
\hline $\mathrm{Al}, \mathrm{cmol}_{\mathrm{c}} \mathrm{kg}^{-1}$ & $4.557(0.310)$ & $1.821(0.196)$ & $<0.001$ & $<0.001$ & 0.885 \\
\hline $\mathrm{C}$, percent dry mass & $14.5(0.9)$ & $23.4(2.4)$ & 0.001 & 0.001 & 0.017 \\
\hline
\end{tabular}

${ }^{1}$ A significant Site $\times$ Year interaction effect indicates that there was not a meaningful year effect.

\section{Discussion}

\subsection{Pit and Pin Block Temporal Soil Change}

Comparison of 1967 and 1997 profiles found significant reduction over time of exchangeable $\mathrm{Ca}$ and $\mathrm{Mg}$ concentrations by about an order of magnitude at all four sites and all depths. These changes were accompanied by smaller but significant decreases in $\mathrm{pH}$ and increases in exchangeable $\mathrm{Al}$ [11]. The period of the 1960s through 1980s was one 
of high sulfate deposition in the northeastern USA, with the highest deposition levels in the region of northwestern PA, peaking during the 1970s [9]. A National Acid Deposition Program monitoring site on the Allegheny National Forest in the vicinity of our study sites reported its highest sulfate deposition of $51.0 \mathrm{~kg} \mathrm{ha}^{-1}$ in 1979 , its first full year of operation, and highest nitrate deposition of $27.6 \mathrm{~kg} \mathrm{ha}^{-1}$ in 1981 . These values dropped to $6.9 \mathrm{~kg} \mathrm{ha}^{-1}$ sulfate and $9.5 \mathrm{~kg} \mathrm{ha}^{-1}$ nitrate in 2017 [30]. Reduction in exchangeable base cation concentrations, coupled with mobilization of ionic Al, has been linked to sulfateinduced cation leaching and is considered to be one of the major impacts of acid deposition air pollution in affected regions [5,31]. The timing of this soil change observed on our sites is consistent with a peak depletion of soil exchangeable cations in the mid-1970's, inferred from long term mass balance studies in the northeastern USA [14]. On unglaciated portions of the Allegheny Plateau, of which our four study sites are examples, sugar maple health and growth declines in the 1980s have been linked to depletion of base cations, which resulted in imbalanced nutrition and exaggerated response to stress, such as insect defoliation [32,33].

With the dramatic recent reduction in acid deposition in the northeastern USA, including a greater than $80 \%$ decline in sulfate deposition from peak levels to 2017 [9], there is a question of whether soils are beginning to recover from this acidification event. Our data comparing soil chemistry from 1997 to 2017 shows the strongest change in the uppermost portion of the soil profile, primarily in the Oa and A horizons. Here, $\mathrm{Ca}$ and $\mathrm{Mg}$ concentrations in 2017 approached levels measured in 1967, before air pollution acidification peaked. Chemistry of E and B horizons appear more similar to 1997 results, with some indications of continued loss of base cations, with small but significant losses of Ca at the 50 and $100 \mathrm{~m}$ depths (Table 1). In the uppermost $\mathrm{E}$ and B horizons, there was a sharp decline of $\mathrm{Al}$ from 1997 to 2017, although this effect was highly variable among the four sites.

Pin block data support the results from the pits in the zone of the $\mathrm{Oa}$ and A horizons, providing robust quantitative evidence of an increase in $\mathrm{Oa} / \mathrm{A}$ horizon thickness and mass per unit area (Table 2). Both the pit and pin block data show increasing $\mathrm{Ca}$ and $\mathrm{Mg}$ concentrations in the $\mathrm{Oa} / \mathrm{A}$ horizons, while these data were only significant in the pit samples due to significant site $\times$ year interaction effects in the pin block samples. For both pit and pin block samples, a strong reduction in exchangeable Al concentrations was highly significant in the $\mathrm{Oa} / \mathrm{A}$ horizon (Tables 1 and 2).

The increase in base cations and organic carbon seen in the soil profile graphs (Figures 2,3 and 6) and the pin blocks appears to be due more to an expansion of the $\mathrm{Oa} / \mathrm{A}$ horizon into the depth range of the profile occupied in previous sampling by an $\mathrm{E}$ or $\mathrm{B}$ horizon, more than by a change in the chemistry of the $\mathrm{Oa} / \mathrm{A}$ horizon. The relationship between organic carbon and exchangeable base cation concentrations is similar for all three years (Figure 6). In 2017, a greater portion of the Oa/A samples met the definition of an Oa horizon with $\geq 20 \%$ organic carbon content. Comparison with 1967 data is limited as there are no pin block data to quantitatively evaluate the forest floor and only one pit per site in 1967. However, in the 1967 pits, Oa and A horizons together ranged from 3 to $6 \mathrm{~cm}$ thick, with an arithmetic mean of $3.7 \mathrm{~cm}$, compared to a mean of $3.2 \mathrm{~cm}$ thick in the 16 pits sampled in 1997 and $6.1 \mathrm{~cm}$ in 2017 . The increase in thickness, mass per area, and organic carbon content observed in the Oa/A horizon in 2017 is novel compared to the 1967 and 1997 results. Therefore, although the base cation concentrations in the upper part of the profiles in 2017 and 1967 are similar, these horizons were more carbon-rich in 2017 compared to both prior sampling years, showing that the surficial horizons did not return to conditions measured 50 years earlier but rather have reached a novel state.

\subsection{Comparison with Other Studies}

A number of other studies have resampled soils during the recent period of declining acid precipitation. Their findings are summarized here with years sampled in parentheses. At a large number of sites across the glaciated portion of northeastern USA and adjacent Canada, decreases in $\mathrm{Al}$ in $\mathrm{O}$ horizons and increases in $\mathrm{pH}$ in $\mathrm{O}$ and $\mathrm{B}$ horizons were 
reported (1985-2010) $[17,18]$. These changes were relatively small and were interpreted to represent early phases of recovery from acidification. In New Hampshire and Maine, USA, Fraser et al. [34] found increases in organic $\mathrm{C}, \mathrm{Ca}, \mathrm{Mg}$, and decreases in $\mathrm{Al}$ concentrations in the $\mathrm{Oa}$ and decreases in base cations and an increase in $\mathrm{Al}$ in the $\mathrm{B}$ horizon (2001-2015), suggesting recovery in the forest floor, promoted by an increase in $C$ storage but continued acidification in $B$ horizons. The dynamics they measured were also relatively small. Similar to our study, they suggest a mixed response with trends in the forest floor and mineral soil in opposite directions. In the Adirondack Mountains of New York, Lawrence et al. [35] found small changes consistent with recovery (1997-2017) including a small but significant increase in B horizon exchangeable $\mathrm{Ca}$; their results in the Oa horizon were mixed, with some sites recovering and others continuing to show decreases in $\mathrm{Ca}$.

Berger et al. [36] found small increases in soil $\mathrm{pH}$ and exchangeable Ca and $\mathrm{Mg}$ (1984-2012) in beech forests in Austria, with larger changes observed in shallower soil horizons and at sampling sites closer to tree boles, in a zone affected by stemflow. Oulehle et al. [37] in a spruce forest in the Czech Republic found over a period of strongly declining acid deposition (1995-2009) that the forest litter and Oa carbon pool decreased. They attributed this change to an inhibition of microbial activity and decomposition processes during higher acid loading. Similarly, in pine forests in Germany, Prietzel et al. [38] in an unusually long study (1974-2019) found that $C$ stocks and base saturation decreased until about 2004 and then reversed showing signs of recovery in upper soil layers since then.

Our results are mostly comparable to this sampling of other studies of soil change during periods of declining acid deposition in eastern North America and Europe in that they show signs of recovery primarily in the uppermost soil layers and mixed changes or slight continued acidification in deeper layers. Our finding of a strong increase in carbon storage in the Oa/A horizon was detected by Fraser et al. [34] in New Hampshire and Maine but not in other studies, although an increase in Oa horizon thickness was also detected in response to a liming experiment in a catchment impacted by acid deposition in the Adirondacks [39]. Some of these other studies sampled by depth increment or attempted to sample $\mathrm{O}$ horizons separately, typically without providing organic carbon data to justify that this break had been made properly within the soil profile. Given that this distinction is artificial and difficult to accurately make in the field, and that deciduous forest soils typically have a relatively thin forest floor with organic carbon values frequently clustered around the $20 \%$ cutoff for O horizons, we suggest that future studies pay closer attention to organic carbon changes coupled with base cation and $\mathrm{Al}$ concentrations, and consider the horizons with humified organic matter as a whole. The European studies that paid closest attention to $C$ stocks in conjunction with acidification recovery found the opposite trends in C storage to ours, with a declining carbon pool in the Oa horizon [37]. This may be difficult to interpret as the European sites have a more complicated and longer history of manipulation [38].

\subsection{Mechanisms of Recovery from Acidification}

Much of the change we observed in these soils from 1997 to 2017 appears to be a result of a change in organic matter processing, increasing the organic carbon content of the $\mathrm{Oa} / \mathrm{A}$ horizons and uppermost $\mathrm{E} / \mathrm{B}$ horizons, leading to exchangeable $\mathrm{Ca}$ and $\mathrm{Mg}$ concentrations approaching those observed in 1967, and a strong decrease in exchangeable Al concentrations. Several processes that could be components of acidification recovery may contribute to changes including greater and more efficient recycling of organic matter and associated nutrients [37,38], a reduction in solubility of $\mathrm{Al}$ [40], increased soil organic matter stabilization by metals [41], and relocation of deeper soil nutrient pools toward the surface through root and fungal uptake [42]. Pin block data indicate a substantial decrease in Oie mass. This could reflect a reduction in litter inputs or an increase in decomposition in the upper relatively young and less decomposed portions of the forest floor. An expansion of earth worm activity could also result in the loss of Oi and Oe horizons. However, earthworm activity, which we did not observe at any of our sites 
in either sampling year, would probably also result in a loss of Oa horizons, leaving A horizons as the dominant horizon at the top of the profile. Furthermore, earthworm activity is rare in soils with such low $\mathrm{pH}$ and base saturation [43]. The increase in the mass of the Oa and A horizons, coupled with an increase in the organic carbon is inconsistent with an increase in earthworm activity. Rather the decrease in the Oi and Oe horizons appears to be compensated by an increase in the Oa and A horizons. Therefore, while decreased litterfall or increased decomposition may be the most likely cause of the Oie decline, a decrease in decomposition or an increase in humus stabilization may be responsible for the increase in the $\mathrm{Oa}$ and A horizons.

Other factors besides recovery from acid deposition may have contributed to the soil change we observed. In 2017, the forest stands on our study sites increased in basal area at two sites and the number of stems per area increased at three sites (see supplemental Tables S1-S4). There were various changes in species abundance, though no clear trends; all stands remain relatively diverse mixed deciduous forest. Given that the soil changes we highlight were observed at all four sites and there was not a consistent vegetation change across all four sites, change in vegetation does not seem like the driving factor. Another potential driver is the changing climate. On the Allegheny Plateau, the climate has become warmer and wetter over the last period 1950-2019 [44]. Average cumulative precipitation from May-September has increased by $1.8 \mathrm{~cm}$ per decade, and the average minimum air temperature from March-May has increased $0.16{ }^{\circ} \mathrm{C}$ per decade. Additionally, July minimum temperatures have increased an average of $0.26{ }^{\circ} \mathrm{C}$ per decade. These climate dynamics could affect organic matter decomposition processes in ways that interact with changes in soil organic matter stabilization due to changes in $\mathrm{pH}$ and availability of metal cations.

On these parent material Ultisols, kaolinite is the dominant clay mineral $[2,4,19]$. While clays generally provide the negatively charged surface sites that are responsible for cation exchange capacity, these clays are very limited in providing these sites. In this case, decomposing organic matter, and negatively charged surface sites on stabilized soil organic matter are significant sources of cation exchange. This is especially evident in the Oa and A horizons, the soil layers where humified organic matter and mineral matter mix, as evidenced by the positive correlation between exchangeable $\mathrm{Ca}$ and organic carbon concentrations (Figure 6). The increase in exchangeable cation concentrations observed between 1997 and 2017 is associated with an increase in organic carbon storage in this soil layer. There appears to be a shift from A to Oa horizons at the surface of these soil profiles, with the break between these two horizons defined as $20 \%$ carbon. This increase in soil organic matter stabilization in surficial soils may be attributable to biotic or chemical processes [41].

Weatherable minerals, particularly $\mathrm{Ca}$ and $\mathrm{Mg}$ bearing minerals are depleted through millennia of soil development on these unglaciated soil profiles [2,4,19]. Furthermore, on plateau-top sites hydrologic pathways to bring weathering products from very deep regolith or bedrock are lacking [45]. Thus the ability of geologic inputs to restore base cation supplies is very limited. As such, biologic processes to recycle base cations and limited inputs of base cations from atmospheric deposition [30] may be the primary mechanisms promoting recovery of base cation stocks from acidification. Increase in organic matterassociated nutrients - Ca and Mg (and K was included in our data [20] but not reported in this manuscript) coupled with a decrease in Al may indicate more efficient recycling of organic matter and nutrients. Improved forest health might further contribute to more efficient recycling.

\section{Conclusions}

This record of fifty years of soil change may be one of the longer records of forest soil dynamics in the USA and the only record of acidification and the start of recovery for primary forest sites on unglaciated soils. Protected long-term monitoring sites are rare but are invaluable in documenting the results of a changing chemical and physical environment, 
providing feedback to policy makers on the success of pollution control policy and to land managers in informing sustainable management practices. As these plateau top sites are relatively insulated from lateral groundwater inputs and depauperate of weatherable primary minerals, mineral weathering processes, a primary mechanism contributing base cations and buffering $\mathrm{pH}$, is very limited and thus recovery may be an exceedingly slow process. However, strong signs of recovery of base cations coupled with decreasing $\mathrm{Al}$ concentrations and increases in organic carbon storage in surficial horizons were observed and may indicate the strong role that organic matter recycling plays in maintaining the fertility of these sites. A decrease in leaching of base cation nutrients, coupled with a decrease in Al solubility, both due to a decrease in mobile acid anions, may increase the efficiency of biomass recycling processes, which may be further enhanced by the role metals play in the stabilization of soil organic matter. Although we hypothesized that recovery from acidification would be minimal on these mineral-depauperate unglaciated soils, the recovery we observed is similar to that observed by others on younger, glaciated soils, which may point to the important role that organic matter recycling by forest vegetation plays in building stocks of soil nutrients.

Supplementary Materials: A supplemental materials is available online at https:/ www.mdpi.com/ 2571-8789/5/1/16/s1. Figure S1: Location of the four soil sampling sites on the Allegheny National Forest (ANF), northwestern PA, USA. Figure S2: Profile chemistry for $\mathrm{pH}$, and exchangeable Ca, $\mathrm{Mg}$, and Al. Genetic horizon samples are plotted at the depth of the middle of each horizon. Year sampled is 1967 (blue, dashed line), 1997 (red, dotted line), 2017 (green, solid line), Table S1: Dew Drop (DD) stand composition and structure. Species abbreviations are northern red oak (NRO), red maple (RM), birch (BIR), black cherry (BC), cucumbertree (CUC), sugar maple (SM), striped maple (STM), serviceberry (SVB), and American beech (AB), Table S2: Fools Creek (FC) stand composition and structure. Species abbreviations as in Table S1, with the addition of sweet birch (SB), yellow birch (YB), and white ash (WA), Table S3: Hearts Content (HC) stand composition and structure. Species abbreviations are the same as the previous tables with the addition of white oak (WO), black gum (BGUM), sassafras (SAS), eastern hemlock (EH), white pine (WP), and mountain holly (MTH), Table S4: North Branch (NB) stand composition and structure. Species abbreviations are the same as the previous tables, Table S5. Abbreviations, common names, and Latin binomials for all vegetation species.

Author Contributions: Conceptualization, S.W.B., R.P.L. and S.B.H.; methodology, S.W.B.; formal analysis, R.P.L.; data curation, S.W.B.; writing-original draft preparation, S.W.B.; writing-review and editing, S.W.B., R.P.L. and S.B.H. All authors have read and agreed to the published version of the manuscript.

Funding: This research was partly funded by USDA Forest Service, Allegheny National Forest.

Institutional Review Board Statement: Not applicable.

Informed Consent Statement: Not applicable.

Data Availability Statement: The data presented in this study are openly available in the USDA Forest Service Research Data Archive at https://doi.org/10.2737/RDS-2021-0022 (accessed on 1 February 2021).

Acknowledgments: Field and laboratory work was provided by Reid Garrison, Emily Piché, Samantha Auger, Jeffrey Merriam, and Jane Hislop. John Stanovick provided consultation on design and programming of statistical analyses. The authors thank Don Ross, Greg Lawrence, and two anonymous reviewers whose careful reviews helped us to improve the manuscript.

Conflicts of Interest: The authors declare no conflict of interest. The funders had no role in the design of the study; in the collection, analyses, or interpretation of data; in the writing of the manuscript, or in the decision to publish the results. 


\section{References}

1. de Boucherville Richter, D.; Markewitz, D. Understanding Soil Change: Soil Sustainability Over Millennia, Centuries, and Decades; Cambridge University Press: Cambridge, UK, 2001; ISBN 978-0-521-77171-9.

2. Ciolkosz, E.J.; Waltman, W.J.; Simpson, T.W.; Dobos, R.R. Distribution and genesis of soils of the northeastern United States. Geomorphology 1989, 2, 285-302. [CrossRef]

3. Ciolkosz, E.J.; Waltman, W.J.; Thurman, N.C. Fragipans in Pennsylvania Soils. Soil Horiz. 1995, 36, 5. [CrossRef]

4. Ciolkosz, E.J.; Waltman, W.J.; Thurman, N.C.; Cremeens, D.L.; Svoboda, M.D. Argillic Horizons in Pennsylvania Soils. Soil Horiz. 1996, 37, 20. [CrossRef]

5. $\quad$ Lawrence, G.B.; Fernandez, I.J.; Richter, D.D.; Ross, D.S.; Hazlett, P.W.; Bailey, S.W.; Ouimet, R.; Warby, R.A.F.; Johnson, A.H.; Lin, H.; et al. Measuring Environmental Change in Forest Ecosystems by Repeated Soil Sampling: A North American Perspective. J. Environ. Qual. 2013, 42, 623. [CrossRef] [PubMed]

6. Schmid, P.; Gujer, E.; Zennegg, M.; Bucheli, T.D.; Desaules, A. Correlation of PCDD/F and PCB concentrations in soil samples from the Swiss soil monitoring network (NABO) to specific parameters of the observation sites. Chemosphere 2005, 58, 227-234. [CrossRef] [PubMed]

7. Lawrence, G.B.; Bailey, S.W. Workshop Establishes the Northeastern Soil Monitoring Cooperative. Eos Trans. Am. Geophys. Union 2007, 88, 247. [CrossRef]

8. Vet, R.; Artz, R.S.; Carou, S.; Shaw, M.; Ro, C.-U.; Aas, W.; Baker, A.; Bowersox, V.C.; Dentener, F.; Galy-Lacaux, C.; et al. A global assessment of precipitation chemistry and deposition of sulfur, nitrogen, sea salt, base cations, organic acids, acidity and $\mathrm{pH}$, and phosphorus. Atmos. Environ. 2014, 93, 3-100. [CrossRef]

9. Likens, G.E.; Butler, T.J.; Claybrooke, R.; Vermeylen, F.; Larson, R. Long-term monitoring of precipitation chemistry in the U.S.: Insights into changes and condition. Atmos. Environ. 2020, 245. [CrossRef]

10. Warby, R.A.F.; Johnson, C.E.; Driscoll, C.T. Continuing Acidification of Organic Soils across the Northeastern USA: 1984-2001. Soil Sci. Soc. Am. J. 2009, 73, 274-284. [CrossRef]

11. Bailey, S.W.; Horsley, S.B.; Long, R.P. Thirty years of change in forest soils of the Allegheny Plateau, Pennsylvania. Soil Sci. Soc. Am. J. 2005, 69, 681-690. [CrossRef]

12. Yu, Z.; Chen, H.Y.H.; Searle, E.B.; Sardans, J.; Ciais, P.; Peñuelas, J.; Huang, Z. Whole soil acidification and base cation reduction across subtropical China. Geoderma 2020, 361, 114107. [CrossRef]

13. Billett, M.F.; Parker-Jervis, F.; FItzpatrick, E.A.; Cresser, M.S. Forest soil chemical changes between 1949/50 and 1987. J. Soil Sci. 1990, 41, 133-145. [CrossRef]

14. Likens, G.E.; Driscoll, C.T.; Buso, D.C. Long-Term Effects of Acid Rain: Response and Recovery of a Forest Ecosystem. Science 1996, 172, 244-246. [CrossRef]

15. Bailey, S.W.; Hornbeck, J.W.; Driscoll, C.T.; Gaudette, H.E. Calcium inputs and transport in a base-poor forest ecosystem as interpreted by Sr isotopes. Water Resour. Res. 1996, 32, 707-719. [CrossRef]

16. Fernandez, I.J.; Rustad, L.E.; Norton, S.A.; Kahl, J.S.; Cosby, B.J. Experimental Acidification Causes Soil Base-Cation Depletion at the Bear Brook Watershed in Maine. Soil Sci. Soc. Am. J. 2003, 67, 1909. [CrossRef]

17. Lawrence, G.B.; Hazlett, P.W.; Fernandez, I.J.; Ouimet, R.; Bailey, S.W.; Shortle, W.C.; Smith, K.T.; Antidormi, M.R. Declining acidic deposition begins reversal of forest-soil acidification in the northeastern US and eastern Canada. Environ. Sci. Technol. 2015, 49, 13103-13111. [CrossRef]

18. Hazlett, P.; Emilson, C.; Lawrence, G.; Fernandez, I.; Ouimet, R.; Bailey, S. Reversal of Forest Soil Acidification in the Northeastern United States and Eastern Canada: Site and Soil Factors Contributing to Recovery. Soil Syst. 2020, 4, 54. [CrossRef]

19. Ciolkosz, E.J.; Ranney, R.W.; Peterson, G.W.; Cunningham, R.L.; Matelski, R.P. Characteristics Interpretations and Uses of Pennsylvania Soils, Warren County; Progress Report; The Pennsylvania State University, Agricultural Experiment Station: State College, PA, USA, 1970.

20. Bailey, S.W.; Long, R.P.; Horsley, S.B. Soil Description and Chemistry, Allegheny National Forest, 1997, 2017; Forest Service Research Data Archive: Fort Collins, CO, USA, 2021.

21. Stout, S.L.; Marquis, D.A.; Ernst, R.L. A relative density measure for mixed-species stands. J. For. 1987, 85, 45-47.

22. Marquis, D.A. The Allegheny Hardwood Forests of Pennsylvania; USDA Forest Service; U.S. Government Printing Office: Washington, DC, USA, 1975.

23. Federer, C.A. Organic matter and nitrogen content of the forest floor in even aged northern hardwoods. Can. J. For. Res. 1984, 14, 763-767. [CrossRef]

24. Soil Survey Staff. Keys to Soil Taxonomy, Twelfth Edition; U.S. Department of Agriculture, Natural Resources Conservation Service: Washington, DC, USA, 2014.

25. Robarge, W.P.; Fernandez, I.J. Quality Assurance Methods Manual for Laboratory Analytical Techniques. Revision 1; U.S. EPA. and USDA Forest Response Program; Corvallis Environmental Research Laboratory: Corvallis, OR, USA, 1987.

26. Blume, L.J.; Schumacher, B.A.; Schaffer, P.W.; Cappo, K.A.; Papp, M.L.; van Remortel, R.D.; Coffey, D.S.; Johnson, M.G.; Chaloud, D.J. Handbook or Methods for Acid Deposition Studies Laboratory Analyses for Soil Chemistry; U.S. Environmental Protection Agency, Environmental Monitoring Systems Laboratory: Las Vegas, NV, USA, 1990. 
27. Ross, D.S.; Bailey, S.W.; Briggs, R.D.; Curry, J.; Fernandez, I.J.; Fredriksen, G.; Goodale, C.L.; Hazlett, P.W.; Heine, P.R.; Johnson, C.E.; et al. Inter-laboratory variation in the chemical analysis of acidic forest soil reference samples from eastern North America. Ecosphere 2015, 6, 1-22. [CrossRef]

28. SAS/STAT Software, Version 9.4; SAS Institute, Inc.: Cary, NC, USA, 2012.

29. Littell, R.C.; Milliken, G.A.; Stroup, W.W.; Wolfinger, R.D.; Schabenberger, O. SAS for Mixed Models, 2nd ed.; SAS Institute Inc.: Cary, NC, USA, 2006.

30. NADP National Atmospheric Deposition Program. National Trends Network Data, Site PA29, Kane Experimental Forest. Available online: http:/ / nadp.slh.wisc.edu / (accessed on 27 January 2021).

31. Driscoll, C.T.; Lawrence, G.B.; Bulger, A.J.; Butler, T.J.; Cronan, C.S.; Eagar, C.; Lambert, K.F.; Likens, G.E.; Stoddard, J.L.; Weathers, K.C. Acidic deposition in the northeastern United States: Sources and inputs, ecosystem effects, and management strategies. BioScience 2001, 51, 180-198. [CrossRef]

32. Horsley, S.B.; Long, R.P.; Bailey, S.W.; Hallett, R.A.; Hall, T.J. Factors associated with the decline disease of sugar maple on the Allegheny Plateau. Can. J. For. Res. 2000, 30, 1365-1378. [CrossRef]

33. Long, R.P.; Horsley, S.B.; Hallett, R.A.; Bailey, S.W. Sugar maple growth in relation to nutrition and stress in the northeastern United States. Ecol. Appl. 2009, 19, 1454-1466. [CrossRef]

34. Fraser, O.L.; Bailey, S.W.; Ducey, M.J. Decadal Change in Soil Chemistry of Northern Hardwood Forests on the White Mountain National Forest, New Hampshire, USA. Soil Sci. Soc. Am. J. 2019, 83, S96-S104. [CrossRef]

35. Lawrence, G.; Siemion, J.; Antidormi, M.; Bonville, D.; McHale, M. Have Sustained Acidic Deposition Decreases Led to Increased Calcium Availability in Recovering Watersheds of the Adirondack Region of New York, USA. Soil Syst. 2021, 5, 6. [CrossRef]

36. Berger, T.W.; Türtscher, S.; Berger, P.; Lindebner, L. A slight recovery of soils from Acid Rain over the last three decades is not reflected in the macro nutrition of beech (Fagus sylvatica) at 97 forest stands of the Vienna Woods. Environ. Pollut. 2016, 216, 624-635. [CrossRef] [PubMed]

37. Oulehle, F.; Evans, C.D.; Hofmeister, J.; Krejci, R.; Tahovska, K.; Persson, T.; Cudlin, P.; Hruska, J. Major changes in forest carbon and nitrogen cycling caused by declining sulphur deposition. Glob. Chang. Biol. 2011, 17, 3115-3129. [CrossRef]

38. Prietzel, J.; Falk, W.; Reger, B.; Uhl, E.; Pretzsch, H.; Zimmermann, L. Half a century of Scots pine forest ecosystem monitoring reveals long-term effects of atmospheric deposition and climate change. Glob. Chang. Biol. 2020, 26, 5796-5815. [CrossRef] [PubMed]

39. Melvin, A.M.; Lichstein, J.W.; Goodale, C.L. Forest liming increases forest floor carbon and nitrogen stocks in a mixed hardwood forest. Ecol. Appl. 2013, 23, 1962-1975. [CrossRef] [PubMed]

40. Van Breemen, N.; Driscoll, C.T.; Mulder, J. Acidic deposition and internal proton sources in acidification of soils and waters. Nature 1984, 307, 599-604. [CrossRef]

41. Clarholm, M.; Skyllberg, U. Translocation of metals by trees and fungi regulates $\mathrm{pH}$, soil organic matter turnover and nitrogen availability in acidic forest soils. Soil Biol. Biochem. 2013, 63, 142-153. [CrossRef]

42. Shortle, W.C.; Smith, K.T.; Jellison, J.; Schilling, J.S. Potential of decaying wood to restore root-available base cations in depleted forest soils. Can. J. For. Res. 2012, 42, 1015-1024. [CrossRef]

43. Ross, D.S.; Knowles, M.E.; Juillerat, J.I.; Görres, J.H.; Cogbill, C.V.; Wilmot, S.; D'Agati, K. Interaction of land use history, earthworms, soil chemistry and tree species on soil carbon distribution in managed forests in Vermont, USA. For. Ecol. Manag. 2021, 17, 1-16.

44. Royo, A.A.; Vickers, L.A.; Long, R.P.; Ristau, T.E.; Stoleson, S.H.; Stout, S.L. The Forest of Unintended Consequences: Anthropogenic Actions Trigger the Rise and Fall of Black Cherry. BioScience 2021, 20, 14.

45. Bailey, S.W.; Horsley, S.B.; Long, R.P.; Hallett, R.A. Influence of edaphic factors on sugar maple nutrition and health on the Allegheny Plateau. Soil Sci. Soc. Am. J. 2004, 68, 243-252. [CrossRef] 